九州大学学術情報リポジトリ

Kyushu University Institutional Repository

\title{
Tenebrionidae from the Nansei Islands XI (Coleoptera)
}

Chujo, Michitaka

Hikosan Biological Laboratory, Faculty of Agriculture Kyushu University

https://doi.org/10.5109/24145

出版情報：九州大学大学院農学研究院紀要. 41 (3/4)，pp.197-204，1997-03. Kyushu University バージョン：

権利関係 : 
J. Fac. Agr., Kyushu Univ., 41 (3•4), 197-204 (1997)

\title{
Tenebrionidae from the Nansei Islands XI (Coleoptera)* M ichitaka Chûjô
}

\author{
Hikosan Biological Laboratory, Faculty of Agriculture Kyushu University, Hikosan, \\ Fukuoka 824-07, Japan \\ (Received November 29, 1996; Accepted December 17,1996)
}

\begin{abstract}
Eleventh report on the Tenebrionidae from the Nansei Islands, Japan, treats the tribe Leiochrini including description of a new subspecies, Derispia japonica yaeyamana from the Yaeyama Isls. Keys to the genera and species, and distributional data of species are presented.
\end{abstract}

\section{Tribe LEIOCHRINI from the Nansei Islands}

Lewis, 1894, Ann. Mag. Nat. Hist., [6],13(77): 390. - Gebien, 1940, Kat. Tenebr., 2: 431(556). - Kaszab, 1946, Verlag Ungar. Naturwiss. Mus., 221pp.; id., 1961, Acta Zool. Acad. Sci. Hungaricae, 7(1-2): 139-184, 45 figs.; id., 1961, loc. cit., 7(3-4): 433-466, 21 figs.; id., 1961, Ann. Hist. -nat. Mus. Nat. Hungarici, 53: 357-380. - Miyatake, 1961, Trans. Shikoku Ent. Soc., 7(1-2): 33-40, 9 figs.

Key to the genera of the Leiochrini from the Nansei Islands

1 Tarsal segments simple, from 1st to penultimate segments with under surface not prolonged, every tibia without keel on out side, elytra with punctate-striae . . . . . . .

*............ Derispia Lewis, 1894

1' Tarsal segments except for basal and terminal segments with apical parts flabellate, every tibia with a keel on outside, elytra without punctate-striae

Leiochrodes Westwood, 1883

\section{Derispia Lewis \\ Type: D. maculipennis Lewis, 1894}

Lewis, 1894, Ann. Mag. Nat. Hist., [6],13(77): 389. - Kaszab, 1920, Nova Guinea, 13(3): 213-499, Pl. 9-11; id., 1939, loc. cit., (n. ser.), 3: 185-267; id., 1946, Verlag Ungar. Naturwiss. Mus., Budapest, III: 41-115, Pl. 1; id., 1961, Ann. Hist. -nat. Mus. Natio. Hungarici, 53: 357-380, 15 figs.; id., 1961, Acta Zool. Acad. Sci. Hungaricae, 7(1-2): 139184, Figs. 1-48.; id., 1961, loc. cit., 7(3-4). - Miyatake, 1961, Trans. Shikoku Ent. Soc., $7(1-2): 33-39$.

* Contribution from the Hikosan Biological Laboratory, Faculty of Agriculture, Kyushu University, Hikosan (Ser. 4, No. 16). 


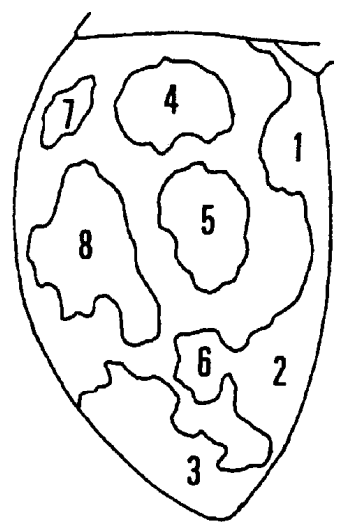

I a

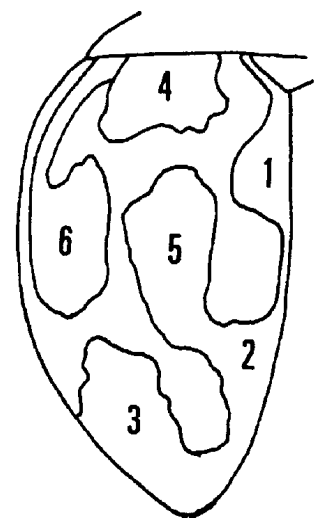

I b

Fig. 1. Tentative numbers of left elytral maculae. la: Derispiajaponica group; lb: D. miyatakei.

Key to the species of the genus Derispia from the Nansei Islands

1 Elytron with 6 spots as tentatively numbered as in Fig. la

1' Elytron with 8 spots as tentatively numbered as in Fig. 1b

2 Pronotum mostly black, no. 1 spot continuous with no. $5,2.2 \mathrm{~mm}$

D. shibatai Chûjô et Miyatake

2' Pronotum wholly reddish brown, no. 1 spot separated from no. 5, 2.4-2.6mm

D. miyatkei Masumoto

3 Elytra with rather deep punctate-striae, interstices convex, 2.8-3.3mm

D. amamiana Miyatake

3' Elytra with very shallow punctate-striae, interstices scarcely convex ......................... 4

4 Pronotum black except for marginal area, elytral interstices with a very fine and rather dense row of punctures on median part, no. 4 spot of elytral macula often very small, no. 7 sometimes completely reduced, $2.5-2.7 \mathrm{~mm}$ D. akitai Masumoto

4' Pronotum reddish brownn or sometimes black in narrow part, elytral interstices with a row of punctures on median part, the punctures somewhat larger and sparser, nos. 4 and 7 spots of elytral maculae of ordinary size each

5 Antennae with 4th to 10th segments black, pronotum evenly brown, interstices with a row of punctures rather large and dense, nos. 6 and 8 spots of elytral maculae conjoined together in many individuals, $2.7-3.0 \mathrm{~mm}$

...... D. japonica yaeyamana subsp. nov.

5' Antennae with 5th to basal half of terminal segments black, pronotum darkened medioposteriorly, interstices with a row of punctures much smaller and sparser, nos. 6 and 8 spots of elytral maculae separated, $2.8-2.9 \mathrm{~mm}$ D. japonica japonica Kaszab 


\section{Derispia akitai Masumoto, 1994}

Derispia akitai Masumoto, 1994, Ent. Rev. Japan, 49(1): 42, Fig. 1 (Kumejima Is.). Spec. exam.: 2 exs., Mt. Darumayama, Kumejima Is., Nansei Isls., 6-8. vi. 1994, T. Ueno leg. Gen. distr.: Japan [Nansei Isls. (Kumejima Is.)].

\section{Derispia amamiana Miyatake, 1961}

Derispia amamiana Miyatake, 1961, Trans. Shikoku Ent. Soc., 7(1-2): 37-38, Figs. 3 \& 7 (Amami-Oshima Is.). - Masumoto, 1994, Ent. Rev. Japan, 49(1): 44, Fig. 4.

= japonica: M. T. Chûjô, 1966, J. Fac. Agr., Kyushu Univ., 14(1): 16. - Nakane \& Masumoto, 1969, Ins. \& Nat., Tokyo, 4(8): 28. - M. T. Chûjô, 1977, Esakia, Kyushu Univ. Publ. Ent., (10): 9.

Spec. exam.: 2 exs.(Japan-U.S.), Yuwan, Amami-Oshima Is., 29-31. vii.1963, Y. Hirashima leg.; 4 exs. (Japan. -U.S.), Yuwan, Amami-Oshima Is., 31. vii. 1963, Y. Hirashima leg.; 1 ex.(Japan-U.S.)(at light), Yuwan-dake, Amami-Oshima Is., 6. viii. 1963, T. Okada leg.; 12 exs., see M. T. Chûjô (1966); 3 exs., see M. T. Chûjô(1977).

Gen. distr.: Japan [Nansei Isls. (Amami-Oshima Is.)].

\section{Derispia japonica japonica Kaszab, 1961}

Derispiajaponica Kaszab, 1961, Acta Zool. Acad. Sci. Hungaricae, 7(1-2):160\& 181, Figs. 42, 43 \& 46 (Okinawa-Honto Is.). - M. T. Chûjô, 1966, J. Fac. Agr., Kyushu
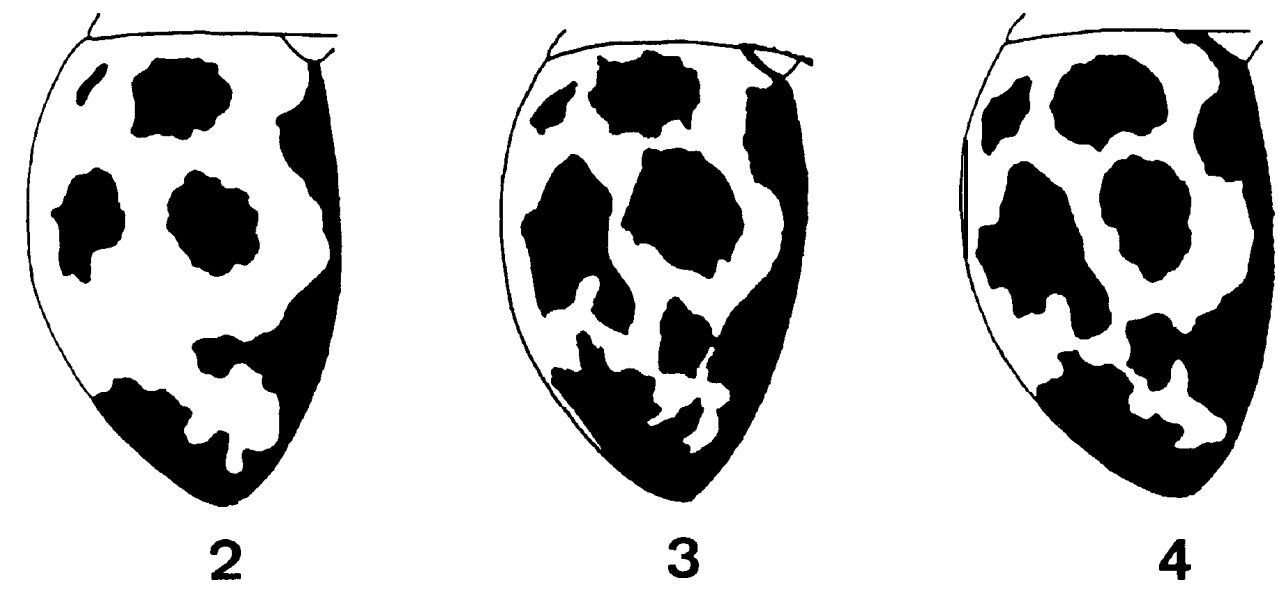

Figs. 2-4. Left elytral maculae of Derispiae species. 2: D. akitai Masumoto; 3: D. amamiana Masumoto; 4: D. japonica japonica Kaszab. 
Univ., 14(1): 16. - Nakane \& Masumoto, 1969, Nat. \& Ins., Tokyo, 4(8): 28. - M. T. Chûjô, 1978, Esakia, Kyushu Univ. Publ. Ent., (11): 65; id., 1978, loc. cit., (12): 5; id., 1979, loc. cit., (14): 38-39; id., 1985, Col. Japan, in Color, Hoikusha, Osaka, 3: 312, PI. 52, Fig. 14. - Sawada, 1986, Coleopterist's News, Tokyo, (73): 3. - Hirashima et al., 1989, Check List, Jap. Ins., (1): 425. - Iwata \& Ando, 1990, Coleopterist's News, Tokyo, (91): 7. - Asahina et al., 1995, Jpn. Wildlife Res. Center, Tokyo: 282.

Spec. exam.: 45 exs., Hyakuna, Okinawa-Honto Is., Ryukyus, 18. vi. 1970, H. Makihara leg.; 1 ex., Chinen, Okinawa-Honto Is., Ryukyus, 8. vii. 1977, H. Makihara leg.; 3 exs., Kudeken, Okinawa-Honto Is., Ryukyus, 20. iv. 1979, H. Makihara leg.; 10 exs., Agunijima Is., Ryukyus, 25. viii. 1989, T. Ueno leg.; 13 exs., Sueyoshi Park, OkinawaHonto Is., Ryukyus, 4. vi. 1994, T. Ueno leg.; 3 exs., see M. T. Chûjô(1977); 37 exs., see M. T. Chûjô(1978).

Gen. distr.: Japan [Nansei Isls. (Amami-Oshima Is., Okinawa-Honto Is. and Agunijima Is.].

\section{Derispia japonica yaeyamana subsp. nov.}

This subspecies is closely related with $D$. japonica Kaszab, 1961, from Okinawa Is., but is distinguished by the following characters: antennae with 4th to 10th segments balck, pronotum evenly brown, interstices with a row of punctures rather larger and denser, nos. 5 and 8 spots of elytral maculae often conjoined each other, no. 3 not reaching elytral margin.

Length: $2.6-3.0 \mathrm{~mm}$. Width: 2.2-2.6mm.

Holotype: male (Type no. 3045, preserved in Kyushu Univ.), Yonehara, Ishigakijima Is., Nansei Isls., 5-6. VII. 1993, H. Kojima leg. Paratopotypes: 7 males \& 9 females, same collecting data as holotype. Paratypes: male \& female (Japan-U. S. Co-op. Sci. Programme), Nakara-gawa, Iriomotejima Is., Nansei Isls., 5. x. 1993, K. Morimoto leg.; male \& female (J. -U. S.), Yoshihara, Ishigakijima Is., Nansei Isls., 15. x. 1993, K. Morimoto leg.; male, Nakara River, Iriomotejima Is., Nansei Isls., 25-26. vi. 1970, H. Makihara leg.; male, Sonai, Iriomotejima Is., Nansei Isls., 6. iv. 1973, H. Irie leg.; male, Sonai, Iriomotejima Is., Nansei Isls., 4. v. 1974, H. Irie leg.; male, Kampire-fall, Iriomotejima Is., Nansei Isls., 14. iv. 1975, H. Irie leg.

Gen. distr.: Japan [Nansei Isls. (Ishigakijima Is. \& Iriomotejima Is.)].

\section{Derispia miyatakei Masumoto, 1994}

Derispia miyatakei Masumoto, 1994, Ent. Rev. Japan, 49(1): $42-43$ (Okinawa-Honto Is.). Spec. exam.: 20 exs., Shikina, Okinawa-Honto Is., Nansei Isls., 1. vi. 1969, K. Iha leg.; 1 ex., Sueyoshi Park, Okinawa-Honto Is., Nansei Isls., 24. iv. 1988, T. Ueno leg.; 2 exs., Afuso, Onna V., Okinawa-Honto Is., Nansei Isls., 27. vi. 1990, T. Ueno leg.; 2 exs., Sueyoshi Park, Okinawa-Honto Is., Nansei Isls., 4. vi. 1994, T. Ueno leg. Gen. distr.: Japan [Nansei Isls. (Okinawa-Honto Is.)]. 


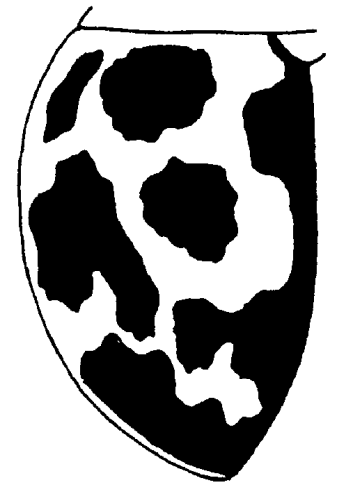

$5 a$

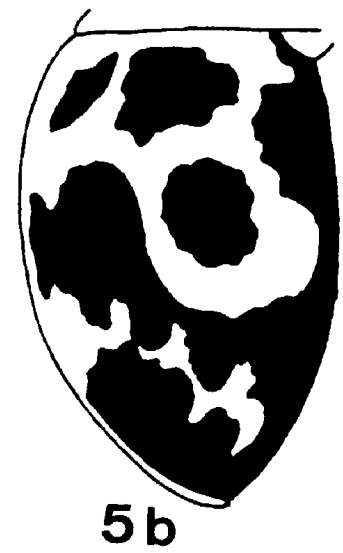

Fig. 5. Left elytral maculae of Derispia japonica yaeyamana subsp. nov. 5a: Separate type in rare case. 5b: Conjoined type in most cases.

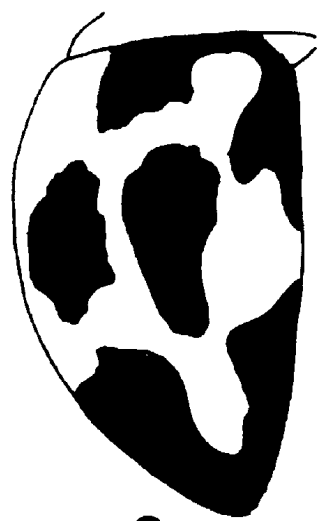

$6 a$

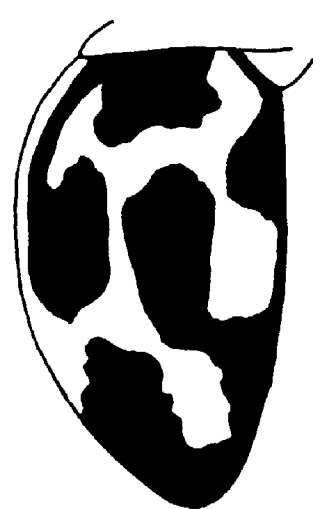

$6 \mathrm{~b}$

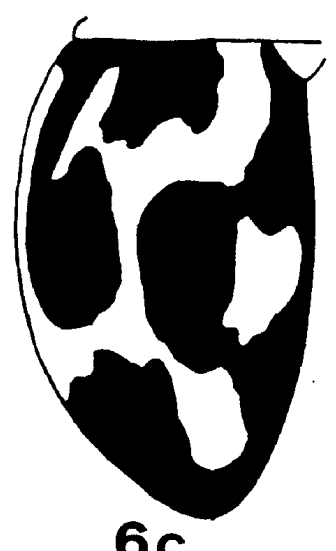

$6 c$

Fig. 6. Left elytral maculae of Derispia miyatakei Masumoto. 6a-c: Showing individual variations of maculae. 


\section{Derispia shibatai Chûjô et Miyatake}

Derispia shibatai Chûjô et Miyatake, 1961, Trans. Shikoku Ent. Soc., 7(1-2): 35, 38-39, Figs. 4 \& 8 (Amami-Oshima Is.). - Masumoto, 1994, Ent. Rev. Japan, 49(1): 43-44, Fig. 3.

=klapperichi: M. T. Chûjô, 1966, J. Fac. Agr., Kyushu Univ., 14(1): 16-17. - Nakane \& Masumoto, 1969, Nat. \& Ins., Tokyo, 4(8): 28 . - M. T. Chûjô, 1977, Esakia, Kyushu Univ. Publ. Ent., (10): 9; id., 1978, loc. cit., (11): 65; id., 1985, Col. Japan in Color, 3 : 312, Pl. 52, Fig. 15. - Hirashima et al., 1991, Check List, Jap. Ins., 1: 425.

Spec. exam.: 1 ex.(J. -U. S.), Nakijin, Okinawa-Honto Is., Ryukyus, 12. iv. 1964, T. Takara leg.; 7 exs., Shikina, Okinawa-Honto Is., Ryukyus, 1. vi. 1985, H. Irie leg.; 1 ex., see M. T. Chûjồ(1978).

Gen. distr.: Japan [Nansei Isls. (Amami-Oshima Is.).

\section{Leiochrodes Westwood \\ Type: L. fulvicollis Westwood, 1883}

Westwood, 1883, Tijdschr. Ent., 26: 69. - Lewis, 1894, Ann. Mag. Nat. Hist., [6], 13(77): 391. - Fairmaire, 1893, Ann. Soc. Ent. France, 62: 26; id., 1898, Ann. Soc. Ent. Belgique, 42: 482. - Kaszab, 1920, Nova Guinea, 13(3): 213-499, Figs. 9-11; id., 1939, loc. cit., (n. ser.), 3: 185-267; Verlag Ungar. Naturwiss. Mus., Budapest, III: 136184, Abb, 231-289.; id., 1961, Ann. Hist.-nat. Mus. Nat. Hungarici, 53: 358; id., 1961, Acta Zool. Acad. Sci. Hungaricae, 7(3-4): 433-466, 24 figs. - Miyatake, 1961, Trans. Shikoku Ent. Soc., 7(1-2): 33 .

= Leiochrota Westwood, 1883, Tijdschr. Ent., 26: 70 .

=Ades Guérin-Ménèville, 1857, in Th. Arch. Ent., 1: 277.

\section{Leiochrodes convexus Lewis, 1894}

Leiochrodes convexus Lewis, 1894, Ann. Mag. Nat. Hist., [6],13(77): 391 (Japan: Honshu \& Kyushu). - Kaszab, 1946, Verlag Ungar. Naturwiss. Mus., Budapest, III : 161-163; id., 1961, Ann. Hist.-nat. Mus. Nat. Hungarici, 53: 358; id., 1961, Acta Zool. Acad. Sci. Hungaricae, 7(3-4): 447. - Miyatake, 1961, Trans. Shikoku Ent. Soc., 7(1-2): 33 \& 40. - Nakane \& Masumoto, 1969, Nat. \& Ins., Tokyo, 4(8): 28. - M. T. Chujo, 1985, Col. Japan in Color, 3: 313, Pl. 52, Fig. 17. - Hirashima et al., 1989, Check List, Jap. Ins., 1: 425 .

Spec. exam.: 1 ex., see M. T. Chûjô, 1985.

Gen. distr.: Japan [Honshu, Shikoku, Kyushu, Tsushima Is. \& Nansei Isls. (Yakushima Is.)]; Formosa, Philippines \& India. 


\section{ACKNOWLEDGEMENTS}

I wish to express my appreciation to Prof. Dr. K. Morimoto, the head of Hikosan Biological Laboratory, for making this study possible and for his continual kind and valuable advices to my study. Also, I am thankful to Assoc. Prof. Dr. 0. Tadauchi and Assist. Prof. S. Kamitani of Entomological Laboratory, Kyushu University for various help. I express my sincere thanks to the following entomologists: Dr. H. Hirashima, Mr. K. Iha, Mr. H. Makihara, Mr. H. Irie and Mr. T. Ueno, for offering of these valuable specimens. Particular thanks are due to Prof. Emeritus, Dr. M. Chûjô of Kagawa University for his various help to my study.

\section{SELECTED REFERENCES}

Asahina, S. et al. 1995 A Check List of Jupanese Wildlife, Invertebmta II. Japan Wildlife Res. Center, Tokyo, $620 \mathrm{pp}$

Iwata, R. and K. Ando 1990 Miscellaneous notes on the genus Derispia. Coleopt. News, Tokyo, (91): 7 (In Japanese)

Chûjô, M. T. 1966 Taxonomic study of the Tenebrionidae (Coloptera) of the Ryukyu Islands. J. Fac. Agr., Kyushu Univ., 14: 1-32, 2 pls

Chûjô, M. T. 1977 Tenebrionidae of the Nansei Islands II (Coleoptera). Esakia, (10): I-19, 2 figs

Chûjô, M. T. 1978 Tenebrionidae of the Nansei Islands III (Coleoptera). Esakiu, (11): 63-80, 12 figs

Chûjô, M. T. 1978 Tenebrionidae of the Nansei Islands IV (Coleoptera). Esakin, (12): I-16, 3 figs

Chûjô, M. T. 1979 Tenebrionidae of the Nansei Islands V (Coleoptera). Esakia, (14): 31-56, 5 figs

Chûjô, M. T. 1982 Tenebrionidae of the Nansei Islands VII (Coleoptera). In "Spec. Iss. Mem. Retir. Emer. Prof. M. Chûjô".87-101, 4 tabs (In Japanese)

Chûjô, M. T. and K. Ando. 1985 Tenebrionidae. In "The Coleoptera of Japan in Color IIl", eds. by Y. Kurosawa, S. Hisamatsu and H. Sasaji, Hoikusha, Osaka. pp. 295-341, pls. $49-58$ (In Japanese)

Hirashima et al. 1989 A Check List of Japanese Insects I. Kyushu Univ. \& Japan Wildlife Res. Center (eds.), 540pp

Kaszab, Z. 1946 Monographie der Leiochrinen. Verlag des Ungarischen Naturwissenschaftlichen. Museums, Budapest. $221 \mathrm{pp}$

Kaszab, Z, 1961 Beiträge zur Kenntnis der Tenebrioniden-Tribus Leiochrini (Coleoptera). Ann. Hist. -nat Mus. Nat. Hungarici, 53: 357-380

Kaszab, Z. 1961 Revision der Tenebrioniden-Gattung Derispia Lewis (Coleoptera). Acta Zool. Acad. Sci. Hungar, 7: 139-184, 45 figs

Kaszab, Z. 1961 Neue Arten der Gattung Leiochrodes Westwood (Coleoptera: Tenebrionidae). Acta Zool.Acad. Sci. Hungar., 7: 433-466, 21 figs

Kato, A. 1989 Tenebrionidae collected from Yonagunijima Island in February. Coleopt News, Tokyo, (85): 7 (In Japanese)

Kato, A. 1991 Four Tenebrionid species collected in Kuchino-erabujima Island. Coleopt News, Tokyo, (94): 3, 1 fig (In Japanese)

Lewis, G. 1894 On the Tenebrionidae of Japan. Ann. Mag. Nat. Hist., 6, 13(77): 377-484, 4 figs

Marseul, M. S. -A. de. 1876 Coléoptères du Japon recueillis par M. Lewis. Ann. Soc. Ent. France, 6(5): 93-142

Masumoto, K. 1994 Note sand descriptions of Japanese Tenebrionidae, VII (Coleoptera). Ent. Rev. Japan, 49(1):41-46, 8 figs

Miyatake, M. 1961 The tribe Leiochrini of Japan (Coleoptera: Tenebrionidae). Trans. Shikoku Ent. Soc., 7(1-2): 33-40, 9 figs

Nakane, T. 1951 Tenebrionidae. In “Iconographia Insectorum Japonicorum”, Hokuryukan, Tokyo, Figs. 3283-3316 (In Japanese)

Nakane, T. 1955 Tenebrionidae. In "Coloured Illustrations of the Insects of Japan (Col.)“: Hoikusha, 
Osaka, Pl. 3, Figs. 778-801 (In Japanese)

Nakane, T. 1963 Tenebrionidae. In "Iconographia Insectorum Japonicorum, Colore nat. edit., 2 (Col.)", Hokuryukan, pp. 219-234, Pls. 110-1 17 (In Japanese)

Nakane, T. and K. Masumoto, 1969. A check list of Tenebrionidae of Japan (Coleoptera)(1). Nature \& Insects, Tokyo, 4(8): 23-29 (In Japanese)

Nakane, T. and K. Masumoto, 1969 A check list of Tenebrionidae of Japan (Coleoptera)(2). Nature \& Insects, Tokyo, 4(9): 32-34 (In Japanese)

Okadome, T. 1973 The Insects Fauna of Yakushima Island, South Japan. Yakushima Educ. Comm., Kumagegun, Kagoshima Pref., Japan. pp. 130-133 (In Japanese)

Sawada,K. 1986 New records of Tenebrionidae from Nansei Islands. Coleopt. News, Tokyo, (73): 3 (In Japanese)

Sawada, K. 1991 Platydema nigropictum Nakane collected in Ishigakijima Island. Coleopt. News, Tokyo, (95): 8 (In Japanese) 